\title{
Autobiographic Discourse in the Films of Jerzy Skolimowski
}

\author{
By Ewa Mazierska \\ Fall 2008 Issue of KINEMA
}

\section{FROM PARTICIPANT TO OBSERVER: AUTOBIOGRAPHIC DISCOURSE IN THE FILMS OF JERZY SKOLIMOWSKI}

IN his native Poland Jerzy Skolimowski is regarded as an artist who conveyed his life and persona on screen more effectively than any other Polish filmmaker: the ultimate autobiographer in and for Polish cinema. This paper attempts to establish how Skolimowski managed to convince his viewers that his films are about him, and how his self-portrait evolved over the years. Before I move to discussing Skolimowski's films and his life, it is worth briefly presenting the concept of autobiography I will use here. Following authors such as Roy Pascal, Jerome Hamilton Buckley and Philippe Lejeune, from the times he revised his notion of autobiographical pact, I regard autobiography not so much as a matter of truthful representation of one's persona and life but of the impression effected by the autobiographer on his reader (see Pascal 1960; Buckley 1984; Lejeune 1989). Accordingly, autobiography is for me always relative, depending, for example, on the form used by the writer and the moment it is created and assessed. Lejeune uses the term "autobiographical pact," but I would prefer to talk about "autobiographical effect," because "pact" suggests conscious decisions on the part of a writer and reader to write and read a particular work as autobiographical. In reality, "autobiographical reading" is usually involuntary, almost automatic. Moreover, "autobiographical effect" is never solely the product of a particular work of art which mirrors somebody's life, but also a product of using one's creative work to shape one's life.

\section{Skolimowski - life and fiction}

In the case of Skolimowski the web of life, narration and artistic creativity is extremely complex. Skolimowski used film and cinema in a wider sense (which includes, for example, interviews he gave) to create and test his different personas, including his future ones, and to correct the official version of himself; to share with the public his private life and even, perhaps, to communicate with those closest to him in a way he could not otherwise achieve. Cinema also made Skolimowski, bringing him fame, assuring him the status of a "cult director" and a major legend of Polish cinema. On the other hand, it severed him from his Polish roots and changed him into a migrant. I will risk the statement that after projecting on screen a certain image of himself, the director had to live up to this image in his private life, which in later instances affected his films.

To illustrate this mutual relation between life and work I would like to mention three episodes from Skolimowski's biography. The first incident, well known in his native Poland, concerns the fate of his fourth full-length feature film made in Poland, Ręce do góry (Hands Up 1967-1981). The film includes a huge portrait of Stalin with two pairs of eyes. The contentious character of this image led to the censors' demand to cut from the film any footage which included it. Skolimowski, however, rejected this request, which led to much unpleasantness from the political authorities, including from Zenon Kliszko, a Party official, regarded as the second most important person in Polish politics at the time, after First Secretary, Władysław Gomułka. The director, however, did not give in and, finally, as he himself confessed in a television interview broadcast many years later, he was offered a passport, which amounted to an invitation to leave Poland. He emigrated, to live life and make films that were without doubt very different from those he previously made in Poland. It is plausible to assume that even if Hands Up! had been Skolimowski's first film, he would have acted in the same principled way with the political authorities. It can also be suggested that his reputation as the chief nonconformist of Polish cinema was a factor in his resolute rejection of the offer to compromise. If he had accepted it, he might have saved his film and continued to make films in socialist Poland, even becoming its leading director, but he would have destroyed the rebellious persona he created in his previous films and in this one. When Hands Up! was eventually taken from the shelf in 1981, rather than allowing it to be released in its original version, Skolimowski added to it a "Prologue," in which he explains the circumstances in which this film was banned in Poland, as well as describing his life concurrent to the period of Hands Up!'s belated release. It thus appears as if the director cannot accept any dissonance 
between his films and his biography - the films always have to be in step with his life.

The second episode concerns Skolimowski's age. According to official documents, he was born in 1936. This date is also "confirmed" in Walkower (Walkover, 1966), in which the main protagonist is about to celebrate his thirtieth birthday. However, in an interview given in Filmówka, a book commemorating the history of the famous Łódż Film School, Skolimowski presents himself as being two years younger than his birth certificate proclaims. The disparity between his real and official age apparently resulted from his poor physical state after the end of the war. The mother of the future director, wanting to save him, falsified his birth certificate, thanks to which he could go to convalesce in Switzerland (quoted in Krubski 1998: 73). The story of Skolimowski's contentious age can be regarded as trivial, but it is also symbolic of the nature of his cinema, as well as of his place in Polish culture. Having two dates of birth (official and unofficial but based on personal testimony) pertains to Skolimowski's position as somebody who, thanks to his films, has more than one persona or "mask," and who can use his power of narration to correct his life. Secondly, it is significant that the director somehow subtracted two years from his life, using narration as the tool of his "rejuvenation."

Such practice reminds one of film stars who want to be regarded as younger than they are according to official documents (Pola Negri apparently had several dates of birth). Youthfulness is also an important motif of films Skolimowski directed; critics regard it as his main obsession. Moreover, Skolimowski's "narrative rejuvenation" increases the temporal distance between himself and the war generation. Having been one year old when the war began, the future director was not only excluded from the anti-Nazi resistance, but could not even have any significant memory of the war. Not remembering times of war is an important trait of Skolimowski's protagonists in such films as Rysopis (Identification Marks: None, 1964) and Bariera (Barrier, 1988), distinguishing them from the generation of war veterans. By presenting himself as somebody who is two years younger Skolimowski thus adds to the similarity between himself and his protagonists. Finally, the story of a wrong date on an official document excellently conveys Skolimowski's distrust of officialdom, especially of any documents produced in socialist Poland. Again, this is also a motif present in many of his films, most importantly in Identification Marks: None and Hands Up! I shall emphasise that I am talking here only about the associations the story of the "wrong date of birth" awakens in me, without assessing its authenticity - for that I have no tools.

The third episode refers to the director's relation with Elżbieta Czyżewska, who was perhaps the greatest Polish female star of the 1960s. This actress played in Skolimowski's short films, Hamleś (Little Hamlet, 1960) and Erotyk (1961), as well as in Identification Marks: None and Walkover, where her presence, however, is reduced to being shown on a photograph. These films trace the development of the director's relationship with Czyżewska - from youthful interest in Little Hamlet, through erotic fascination in Erotyk, to a more complex, multidimensional relationship in his films about Andrzej Leszczyc, Identification Marks: None and, finally, separation and her fading from the director's memory in Walkover. They also mirror a certain ambiguity of this relationship. In particular, we never learn whether Teresa in Identification Marks: None is Leszczyc's wife or is only playing her. Similarly, most critics claim that Czyżewska and Skolimowski were married, while in interviews, including in one I conducted with him, Skolimowski denies this claim and is generally rather taciturn about this chapter of his life (see Lichocka 1994: 7). Indeed, if the director and the actress never married, then do the critics attribute to him something which they ascribe to his cinematic creation, Andrzej Leszczyc? Or, perhaps, it is rather Skolimowski who follows Leszczyc in denying Czyżewska any important role in his life? Again, I do not have answers to these questions and they do not interest me very much. I ask them only to draw attention to the complex web of life and fiction in Skolimowski's case.

\section{Autobiographer as participant}

It is widely agreed that Skolimowski's four early Polish films: Identification Marks: None, Walkover, Barrier and Hands Up!, produce the strongest autobiographical effect of all the films he ever made. However, it is worth grouping them together with Andrzej Wajda's Niewinni czarodzieje (Innocent Sorcerers, 1960) and Roman Polański's Nóż w wodzie (Knife in the Water, 1961), which Skolimowski co-scripted, because they project a somewhat similar image of the protagonist. As is documented both by Wajda and Skolimowski, Wajda invited his younger colleague to collaborate on his film because it was meant to depict the lives of young people, and by this time the future director of Barrier was already regarded as a specialist in the affairs of young people and an epitome of a Polish young man (see Wertenstein 1991: 42). 
Skolimowski fulfilled this expectation by choosing as the main character a young man sharing his interests in jazz, boxing and pretty women, and reserving for himself a small role as a young boxer. Wajda was not content with the overall effect but not because Skolimowski's vision dominated over his or that of the other scriptwriter, Jerzy Andrzejewski, but because it did not come across more forcefully. He claimed that the effect would be much better if the central couple was played by Skolimowski himself and his then girlfriend, Elżbieta Czyżewska, who were the true "innocent sorcerers" of these times (ibid: 42). Most likely Wajda came to this view retrospectively, by watching films in which Skolimowski played main roles. His reasoning appears to be that Skolimowski's work is by "its nature" autobiographical; therefore, in order to make use of Skolimowski's talent one should allow his autobiographism to prevail through using his own body, so to speak. A similar argument is presented by Mariola Jankun-Dopartowa, who claims that Barrier is a flawed film because Skolimowski does not play its protagonist (see Jankun-Dopartowa 1997: 100). In common with Innocent Sorcerers, Skolimowski joined the team of people writing a script for Polański's Knife in the Water and contributed to it immensely (see Polanski 1984: 133) because he knew the idiom of the young generation to which the film's main character belongs - it was his own idiom. Consequently, the "Student" in Knife in the Water has much in common with Skolimowski himself, although he is a "composite" character, bearing similarity both to Skolimowski and Polański. What likens him to Skolimowski are his blond hair, rebelliousness and lack of respect for the older generation (see Uszyński 1990: 8).

Yet, the autobiographical effect is much stronger in the films which Skolimowski himself directed. The most obvious reason for that is the director playing the main part in three of them and having the same name in all three - Andrzej Leszczyc. The main character of Barrier is played by Jan Nowicki and does not have a name; instead, he is described in the script as the "Boy." However, the director offers enough hints within the film's diegesis to allow many viewers and critics to regard the "Boy" as a variation of the character of Leszczyc and, consequently, Barrier as a part of the "Leszczyc tetralogy." The most important was his desire to play in this film, but he could not do so because of pressure the political authorities exerted on him.

Skolimowski explains that he cast himself in Identification Marks: None largely because of the unorthodox way the film was made: it was assembled from short films he shot during his studies at the ód Film School as students' exercises. It was shot for so long and in such difficult circumstances that it would be next to impossible to employ a professional actor; hardly any actor would agree to play "on demand" and practically for free (see Krubski et al 1998: 149). The very difficulty of making Identification Marks: None instantly sets it apart from the rest of Polish film production. Skolimowski's debut was perceived as, in a sense, more than a film - a personal project, even a way of living and over forty years after its premiere it has not lost any of its uniqueness (see Ronduda 2007). Again, this impression was confirmed by the director, who claimed that if not for making Identification Marks: None, he would not persevere as a student in the ód Film School (see Ziółkowski 1967: 9).

As Walkover continued Leszczyc's adventures, it was natural that he again cast himself in the main role. Leszczyc in Walkover is older than in Identification Marks: None and has already gone through some of the experiences mentioned in the first films, most importantly expulsion from the university where he studied engineering, military service, and testing himself at sport. In Hands Up!, Leszczyc is even older and, again, he was once expelled from university, although this time from medical school. In Barrier, although it was shot after Walkover, the main character appears to be younger than Leszczyc in the earlier film, and he is again at university, although about to leave. We see that some details of Leszczyc's life are mutually exclusive, but the general picture of the character is coherent (see Walker 1970: 39). Most importantly, Leszczyc is partly a rebel, partly a drifter. He has problems with commitment to women (who find him very attractive), is critical of everything and dislikes authority, but neither to an extent which would preclude his future integration to society. It is even possible to construe him as a conformist (see Ronduda 2007).

The cumulative effect of playing a similar character, furnished with the director's physicality, was more important in creating an autobiographical effect than attributing to Leszczyc the adventures and personal traits of the "real" Skolimowski. Had Skolimowski played Leszczyc only once, the effect would have been much weaker, even if his incarnation had more in common with him as he is known to his relatives, friends and the general public. Similarly, if in Identification Marks: None a different actor was cast, it would be difficult to link this film with the following three, even if Skolimowski played in them. The "Andrzej Leszczyc effect" can be compared here with the "Antoine Doinel" effect in the films of François Truffaut, except that 
the autobiographical effect of the films of the Polish director is stronger because unlike Truffaut, Skolimowski played his alter ego.

Paradoxically, the impression that we watch the director's autobiography in the "Leszczyc tetralogy" was also facilitated by a certain sketchiness of the main character. As Konrad Eberhardt observes, Leszczyc is more "opaque" than his counterparts in the films which Skolimowski only scripted. We know less about him than about the "Student" from Polański's Knife in the Water and Bazyli from Innocent Sorcerers (see Eberhardt 1982: 116). Janusz Gazda refers to the same feature describing Leszczyc as "abstract" (Gazda 1967: 3). The consequences of Leszczyc's sketchiness are twofold. Firstly, thanks to being only a "skeleton," Leszczyc can accommodate different "bodies": be a somehow disorientated, anti-consumerist and polite man (at least when dealing with officialdom) in Identification Marks: None, and a materialist and arrogant "Boy" in Barrier. Secondly, the opaqueness or elusiveness sets Leszczyc apart from the bulk of the characters of earlier Polish cinema. Before this film Polish cinema (directors and actors) favoured more "definite" characters over those who are always in a state of becoming.

In his "Leszczyc films," as well as in the etudes shot before embarking on Identification Marks: None, Skolimowski used his relatives and friends, most importantly, his two girlfriends, the previously mentioned Eżlbieta Czyżewska and Joanna Szczerbic (who later became his wife), in the roles of girlfriends of the main characters. While watching these four films we witness the development of the director's involvement with these two women. I already mentioned the trajectory of Czyżewska's character from the early shorts to Walkover. In Walkover, Leszczyc looks for a new woman and finds her in Teresa, played by Aleksandra Zawieruszanka, but for a number of reasons their relationship is unsatisfactory. Only in Barrier does he appear to find his true match - a young tram driver, played by Joanna Szczerbic. Testimony of her importance is the fact that, unlike in previous films, the female character is granted some narrative autonomy (see Kornacki 2004) - for a while the camera leaves Leszczyc and follows the driver. In Hands Up!, Szczerbic's character, now named Alfa, is friendly not only with the character played by Skolimowski, but all four male friends. One can presume that this was the role Szczerbic played at this stage, being not only the director's lover, his guarded secret, but part of his extended social life, a friend of his friends.

Another reason why Skolimowski's early works appear autobiographical is their narrative form, especially in the first two productions, Identification Marks: None and Walkover, which is of a "diary" film. ${ }^{(1)}$ The camera in these films follows the main character for a short period of time, respectively one and one and a half days. It practically never leaves him outside the frame, and when it does, the reason is to show what Leszczyc sees or might want to see. It registers events of crucial importance, such as standing in front of the commission, examining draftees in Identification Marks: None and a boxing match in Walkover, as well as those which an outsider will regard as meaningless or trivial, such as walking the streets and talking to passers-by. Everything seems to be interesting and useful to Skolimowski's camera, as it is for the personal narrative of a diarist. There is no hierarchy to the episodes represented; parting with his fiancée has the same status as walking the streets. The films are also centred on Leszczyc in the sense that other people exist in their narratives because of him; they belong to his personal story.

The mode of narration is, as Susan Sontag would put it, "representational" (see Sontag 1994) - we see that something happened, but do not learn why. The lack of conventional psychology is partly compensated for by incorporating in the films various "texts," such as close-ups of manuscripts, songs, poems and photographs. They convey the protagonist's personal thoughts and emotions that are easier for him to share with "us" the viewers, than with people whom he encounters on his journey. Again, such attitudes parallel those of a diarist who prefers to confess to his diary rather than share his thoughts with "real people." Moreover, Leszczyc looks straight into the camera, thus breaking a cinematic taboo, according to which the character behaves as if unaware of the presence of the camera. At times, he is even photographed against a wall, looking straight into the camera, which gives the impression of posing for a portrait.

The saturation with texts and abandoning of conventional plot in favour of loosely joined-up episodes, shot without regard for the rules of professional filmmaking, make Skolimowski's films appear similar to those of Jean-Luc Godard. However, if we are to believe Skolimowski, his films were not a response to Godard's cinema, but were made independently - he did not watch any of Godard's films when making Identification Marks: None and Walkover. Both Skolimowski's similarity to Godard and his uniqueness were recognised 
by Aleksander Jackiewicz, who defended the Polish director from the criticism that his films are merely a response to the French New Wave, by writing, "I will compare him with Godard. Not to question his originality, but to underscore that Skolimowski's films are so much his own" (Jackiewicz 1983: 384).

In Poland the autobiographism of Skolimowski's "Leszczyc films" was augmented by their uniqueness. His whole approach to cinema was different from the vast majority of Polish filmmakers because he focused on the individual, rather than the whole society or generation, and appraised society from the perspective of a single man. Moreover, he did it in an open, even ostentatious way, without apologising for his protagonist (and by extension, himself) for being self-centred and rejecting the ways of his older colleagues and many of his younger ones. This feature was excellently captured by the leading Polish film critics of the time, Bolesław Michałek, Konrad Eberhardt, Zygmunt Kałużyński and the previously quoted Aleksander Jackiewicz.

Michałek, in an article published for the first time in 1966, considered the first two movies with Leszczyc in the context of Polish films made by professional writers and scriptwriters, such as Aleksander Ścibor-Rylski, Jerzy Stefan Stawiński, Józef Hen and Tadeusz Konwicki. This comparison is understandable in the light of Skolimowski's earlier literary and scriptwriting career. Michałek observes that, in most cases, the authors whose novels and scripts were the literary source of some of the best Polish postwar films, in their own movies exhibited no more than professionalism and a desire to entertain the viewers, as opposed to any personal, idiosyncratic vision. Against this background the films of Konwicki and Skolimowski were exceptions because they revealed a "personal touch." The critic wrote about Skolimowski's films:

We find here something which, except for the work of Konwicki, was missing in Polish cinema and which is a precious attribute of modern literature: personal tone, sincerity, the way of talking which is close to ich-roman. I do not mean here an exercise in style, consisting of first-person narration [...], but an intellectual approach: searching for one's own truth about the position in society of a man, who is the author's analogue. Thanks to Skolimowski for the first time a voice was given to the generation that was previously absent from the Polish screen: a generation free from memories of the war, living in the present tense but still having serious problems to adapt to life. (Michałek 1966, quoted in Helman 2002: 145-6)

Konrad Eberhardt argued in a similar vein:

If Skolimowski plays such an important role in Polish cinema, this is because he creates a character who is made up of contradictory elements. This has an immense significance, because Polish postwar cinema conceived a character in one way only: as a product of social and historical processes affecting the whole group. There are very few valuable Polish films in which an ordinary, banal character struggles with reality as it is perceived by him, rather than having his sensitivity and fate moulded by a group... Polish cinema does not like "private topics." Even in third-class productions we find pretences to describing the "fate of epoch," the "tragic fate of the nation." (Eberhardt 1967, quoted in Eberhardt 1982: 129)

Paradoxically, by choosing a protagonist who only speaks on behalf of himself, Skolimowski captured the attitude of a whole generation of those who had no memory of the war and did not experience any event important enough to furnish them with any distinct collective identity. Inevitably, this generation was more individualistic, even self-centred and consumption-oriented than their predecessors, immortalised in films of the Polish School. Moreover, these people wanted to live in the present, as opposed to pondering about their past.

The autobiographism of early films by Skolimowski changes. The protagonist of Barrier is different from Leszczyc in Identification Marks: None and Walkover. Of course he looks different, having the body of Jan Nowicki, but also conveys a different personality, being self-confident, arrogant and articulate, as opposed to the earlier "Leszczycs" who came across as lost in the world and unable to express themselves. However, there are also reasons to situate Hands Up! outside the "Leszczyc canon." This is because, in contrast to Identification Marks: None, Walkover and Barrier, which have an individual at the centre of the film's discourse, Hands Up! does not have any individual protagonist, but a number of characters who one by one take central stage. The character played by Skolimowski does not differ from the rest in the role given to him by the narrative. Moreover, in this film the past, albeit not the war but the Stalinist past, shapes 
the characters' present. Hence, near the end of the first chapter of his career, Skolimowski moved close to a position which dominated Polish postwar cinema and from which he distanced himself when shooting Identification Marks: None.

From the current perspective the early films by Skolimowski come across more as the imaginary biographies of the author than recordings of his actual life. In each film the director chose one stage of his life and one facet of his persona and developed it, at the expense of other stages and facets. Identification Marks: None focuses on his facet as a student who has had enough of studying and wants to "sort out" his life. In Walkover Skolimowski presents himself as a boxer who has had enough of boxing, in Barrier as a man who wants to achieve everything the older generation achieved, but faster and easier, and without any sense of guilt about compromising himself (even if he does compromise himself). In each film the character fails or discovers that he chose a bad path. The "real" Skolimowski was also once a student and a boxer, but when he embarked on filmmaking, he left these "careers" behind, to concentrate on filmmaking. By no means was he a drifter who did not know what to do with his life. On the contrary, according to his colleagues from the ód Film School he was a man of extreme resilience and enterprise, perhaps more talented in this respect than Polański. ${ }^{(2)}$ Even the fact that he was able to make a feature film at the school testifies to his focused personality.

Together these four films speculate about what could happen to Skolimowski had he not became a filmmaker. Perhaps he used the stories of Leszczyc as repositories for his anxieties and hopes, including anxiety concerning finding a place for oneself in contemporary Poland or being forced to leave. In a sense, they also foretell Skolimowski's emigration and his ambivalent attitude to this state, namely his ambition to make films abroad and gain worldwide popularity, but also to retain close contact with Poland. The "premonition" of approaching emigration is alluded to by the motif of a suitcase carried by the protagonist, his interest in "high style," epitomised by Western cars and the form of travel cinema used in them. Moreover, each of the films conveys the character's distrust of and conflict with official structures of power, which also became a feature of the real Skolimowski.

It is not an accident that Skolimowski's films about his alter ego Leszczyc were made in the mid-1960s, rather than the 1940s, 1950s or even early 1960s. In the earlier periods it was difficult to make personal films in Poland. Firstly socialist realism favoured groups rather than individuals and reduced individuals to the sum of specific political and social circumstances. Moreover, this paradigm was hostile to any form of personal narration, such as a diary or improvisation which strengthen the autobiographical effect. Instead, it favoured a rigid, literary script, producing the effect of an objective, impersonal narration. The paradigm that followed, the Polish School, although it allowed individuals to express their own views, also presented them as products of history, especially the Second World War. Again, such a concept of a Pole did not lend itself comfortably to the "freewheeling" narrative style, chosen by Skolimowski. By the early 1960s both socialist realism and the Polish School was exhausted and a space appeared for testing new characters and types of narratives. This period also coincides in European cinema and literature with interest in young people as unique individuals and personal narrations. In the works of filmmakers such as Ken Loach, JeanLuc Godard or Verra Chytilová from a similar period we find characters talking straight to the camera or off-screen explaining their positions. Even if Skolimowski did not know these films, it could be suggested that he breathed the same atmosphere from which they arose.

\section{From participant to observer, from patriot to a citizen of the world}

After Skolimowski left Poland, following the shelving of Hands Up!, in his interviews he construed himself in two ways. One is as a cosmopolitan at ease with any culture and able to take advantage of what they have to offer, without accepting anything wholeheartedly and keeping a safe distance from them (see Boniecka 1983: 8). The other is of an exile, who was forced into a nomadic life by the cruel communist authorities and his own pride and obstinacy, and who in artistic terms did not achieve as much as he could and would have done, had he remained in Poland (see Pogorzelska 2001: 23). The first image likens him to Roman Polański, who never regretted (at least in public) leaving Poland, regarding himself as a model citizen of the world. In the second image Skolimowski projects himself as a kind of new Andrzej Wajda whom he became, had he stayed in Poland. I will not regard these two projections as contradictory because it is plausible to assume that different positions pertain to different stages of Skolimowski's life as an emigrant. Indeed, the first image prevails in the earlier stages of the director's emigration, the second - in its later, less successful 
part. Moreover, people are often glad to be somewhere while simultaneously regretting not being somewhere else or being unhappy where they are, while unwilling to change their place of living. However, one has to admit that there is a tension between Skolimowski's acceptance and rejection of his status as an emigrant and his émigré films reflect this tension.

Following his emigration, Skolimowski continued to play in his films, but only in episodic roles. He appears in such roles in Deep End (1971), Moonlighting (1982), Torrents of Spring (1989), Ferdydurke (1991) and in Polizg (Skid, 1972), for which he only wrote the script. An exception is the "Prologue" to Hands Up, shot in 1981, in which he is the main character. What connects all these films from the perspective of autobiographism, including Hands $U p$, is that in them Skolimowski functions as an observer, looking at the events unfolding in front of his eyes from a position which gives him an insight which participants are lacking. In Deep End it is the position of a Polish emigrant or tourist observing the main characters, Mike and Susan, quarrelling on a train. The fact that he probably does not understand their words (he reads a Polish newspaper) and only draws conclusions from their manner of speaking and body language underscores how, in his infatuation with Susan, Mike is oblivious to the outside world. In Moonlighting Skolimowski plays the mysterious "Boss" who gains access to the adventures of a group of Polish workers, renovating his house while himself living in Poland. In Torrents of Spring the director created for himself a part that does not exist in Turgenev's novel, on which his film is based, of the drunkard friend of Maria, who keeps meeting her at crucial moments of her affair with Sanin. Again, in Ferdydurke Skolimowski created for himself a part that does not exist in Gombrowicz's novel - that of the schoolmaster, who observes all his teachers thanks to installing a contraption in his office, allowing him to open the door of the teachers' office without leaving his desk.

Skolimowski's presence in the "Prologue" to Hands Up! fulfils a number of functions. The most obvious is explaining to the viewer the background to shelving his work and the context of the ending of this ban. The director tells about his dealings with the secret police which demanded his self-censorship of the film, his uncompromising reaction to this demand and reveals how this chain of events affected his subsequent life and career. More importantly, the "Prologue" offers Skolimowski an opportunity to look at Hands Up!, filmmaking and his condition as a director and exiled Pole from the distance of fourteen years separating the two versions of the film. He even claims that the new version became his diary, a recording of his life fourteen years after shooting the first version of the film.

In this diary the "old" Hands Up! is just one of the many elements filling the artist's life, along with travelling, exhibiting paintings in his flat, meeting friends and realising new cinematic projects. Hence, the forty-something Skolimowski of the "Prologue" appropriates the position of the creator, the "father" of his younger self in the main part of the film, if not that of a God, looking at his old film from a different reality. This position is underscored by the camera showing him in profile, gazing, often through windows or portholes, at historical events or their artistic staging. He looks at the old film with sympathy, perhaps even love, but also with a sense of helplessness - his "child" is no longer truly his, the long separation has changed it into a stranger. In one episode of the "Prologue" Skolimowski appears as an actor too, but this time in a film shot by another director, Volker Schlöndorff's Die Fälschung (Circle of Deceit, 1981).

This sequence, apart from revealing what happened to the director at the time his film was meant to be released, allows Skolimowski to draw comparisons between filmmaking and other types of artistic creativity, principally plastic arts. He claims that filmmaking is an arena of illusion, rather than of truthful reflection of reality. In a later scene he also suggests that painting is a superior art, most likely because it is more private; painters do not face censors in the way filmmakers do. Playing in Schlöndorff's film also gave Skolimowski an opportunity to situate the Poland of 1981 on his private political map of the world. He sees it somehow between peaceful (albeit highly bureaucratised and tightly policed) London where he lived at the time and war-ridden Beirut. Such a Poland has a realistic chance for a prosperous existence and democracy, but is also in danger of slipping into bloody conflict and chaos. This observation, although politically rather banal, is important from the perspective of Skolimowski's discourse on Poland and Polishness, as it pertains to the fact that the director stopped seeing Poland as a unique place and instead perceives it now as one of many countries, moderately important for European politics and culture.

This marginalisation of Poland and, consequently, of himself as a Polish exile, is further conveyed in the 
scenes of pro-Solidarity demonstrations in London. The director draws attention to their small scale, the fact that mostly Poles take part in it, and their tight control by the police. Equally, Skolimowski shows himself speaking about Polish affairs at Hyde Park's Speakers' Corner, where anybody is allowed to say anything and all types of self-proclaimed prophets and madmen perform. ${ }^{(3)}$ His perceived lack of importance of Poland and his own marginal position, provides an interesting counterpoint to the story of the original version of Hands Up!, also told in this film (as well as conveyed in its legend), in which he comes across as a very important figure for both the political and artistic life of his country.

Although the prevailing impression Skolimowski conveys in the "Prologue" is that of an observer, even a tourist, there are also moments where we see him as a participant, as in footage of himself taking part in a pro-Solidarity demonstration. This fragment of the film plays a triple role. Firstly, in common with the scene shot in Beirut, it describes what the director did when the ban on his film was lifted. Secondly, it connects the "young" Skolimowski, who directed the first version of Hands Up!, with one in 1981, by representing both as politically opposition filmmakers, in their films taking a stance against the Polish political system. The third function of this scene is to introduce the theme of a Polish opposition artist in London, who from a distance tries to do something for his country.

This last theme is developed or even, as the director himself admitted, overdeveloped, in Success Is the Best Revenge (1984, see Combs 1986: 134). Although in this film Skolimowski does not play the main role, which is given to Michael York, critics tend to see in the pro-Solidarity theatre director named Alex Rodak the emigrant version of Skolimowski (see Klejsa 2006). Perhaps the reason that Skolimowski chose not to play Rodak was to avoid too strong an identification between Rodak and himself. At the same time, in this film Skolimowski, unlike in Deep End, Torrents of Spring or Ferdydurke, does not play any supporting role, which strengthens the impression that Rodak is indeed his alter ego. Off-screen the director pointed to both similarity and difference between himself and Rodak. In a conversation with Richard Combs he confessed that he created Rodak as his own caricature: an exaggeration of his anxieties and vices (see Combs 1986: 133-4). He thus conjured him up in order not to become him in real life, perhaps in a similar way he previously created Leszczyc. Talking with Jerzy Uszyski, on the other hand, he claimed Rodak offers more a portrait of an average Polish artist living in exile than any particular personage, including himself (see Uszyski 1990: 12-3).

Success Is the Best Revenge appears to be highly autobiographical for a number of reasons. One is its sheer packing with information, objects and people pertaining to Skolimowski's life and cinematic interests. Secondly, it is his most personal project, in the sense of diverging from the rules of mainstream, realistic cinema. Its focus on home and border crossing, and the "epistolary" narration (the events unfolded on screen are commented on by Alex's son, Adam, in a letter to his father) links it to "accented cinema" as defined by Hamid Naficy: the cinema produced by emigrants who use film as a tool to communicate their yearning for their lost fatherland (see Naficy 2001). Success Is the Best Revenge also bears similarity with the films Jean-Luc Godard made in the 1980s. The most obvious Success's relative is Passion (1982), which also concerns a Polish director on foreign soil, finding it difficult to complete his project. The third reason for Success Is the Best Revenge's strong autobiographical character is its effect on Skolimowski's subsequent life and career. It changed the director's life dramatically, making him literally and metaphorically homeless. Being the film's producer, he mortgaged his London house to finance this project, became bankrupt and lost his home. This incident also put him off England (see Uszyski 1990: 7) and some years later he moved to the United States.

Alex Rodak is presented as somebody who was educated in a boarding school in Czechoslovakia - the only public school in Eastern Europe. Likewise, Skolimowski attended such a school, where he met such future imminent figures in Czech culture as Václav Havel, Miloš Forman and Ivan Passer (see Uszyński 1990: 4). The fact that Alex's work is celebrated in France where he accepts the Légion d'honneur, the country's highest cultural honour, as one of the best European theatre directors, can be regarded as a reference to the appreciation of Skolimowski's work in France, particularly in the 1960s. The film is largely based on the diary of the director's son, Micha Skolimowski (aka Michael Lyndon), which Skolimowski found by chance and in the roles of Alex's wife, Alicja, and their sons, Skolimowski cast his own wife, Joanna Szczerbic and their sons, Michał and Jerzy (aka Jerry). Another major role, that of Mr. Gienio, leader of the Polish extras, was given to Eugeniusz Haczkiewicz, a Polish man who once lived in the director's house, helped 
him to renovate it and played in Skolimowski's previous film, Moonlighting. Moreover, the Rodaks family lived in the director's real house at the time. Ironically, as I previously mentioned, Skolimowski lost this London property as a result of making Success. The story thus perfectly illustrates the famous phrase by Susan Sontag, "One cannot use the life to interpret the work. But one can use the work to interpret the life" (Sontag 1983: 111).

In Success Is the Best Revenge the contrast between participant and observer is accompanied by the dichotomous citizen of the world - a man attached to one country. (4) The fact that Rodak's work is celebrated in France makes him, if not a model citizen of the world, then at least a citizen of Europe. However, while Rodak's biography points to his cosmopolitanism, his obsessive interest in Polish affairs, as revealed by his ambitious theatrical project of staging in London an avant-garde play about Polish martial law, suggests that deep down he remains a Pole through and through, as conveyed by his name, Rodak (the Countryman). This project can be seen as very idealistic, but bringing it into existence forces Rodak to abandon basic moral principles, including entering into shabby deals with a rich pornographer, Dino Montecurva (Kurwa is Polish for whore). ${ }^{(5)}$

The complex relations of Rodak with Polishness are reflected in the relationships with his family, other Poles, as well as in his theatrical work. For two years Alex lived away from his wife and sons because he could not leave the military-ruled Poland, while they stayed in London. Alicja not only struggles to conform to the cosmopolitan culture in which Alex is immersed, but even has problems learning English. Her identity is distinctly Polish; she is weary of Alex's theatrical project that would make them enemies of the Polish authorities and bar them from returning to their country. Moreover, she objects to her sons following in their father's footsteps as conveyed by her addressing them "You cosmopolitan idiots." On the other hand, Rodak is exasperated by his wife's provinciality and narrow-mindedness and whenever possible, avoids her. Alex feels close to his older son, Adam, but their relationship is troubled by their competition for the love of their country, culminating in Adam's decision to go to Poland, when his father play has its premiere in London.

Rodak interacts even more reluctantly with his other fellow countrymen. He gets in contact with them, plays football with them, appeals to their patriotism, but only to use them as extras in his show which should appear as their spontaneous performance. Polish emigrants come across as a materially and culturally impoverished herd, easily excited and manipulated. The only member of this crowd whom Skolimowski endows with an individual identity, Mr. Gienio, is reduced to an animal-like existence. He is practically homeless, camping in the back of a restaurant, deprived of basic facilities and privacy.

The lack of interest and empathy with the physical workers differentiates Skolimowski's film from Godard's Passion, in which the Polish director Jerzy (Jerzy Radziwiłowicz) enters into a complex relationship, which includes erotic interest, with the factory worker, Isabelle (Isabelle Huppert). Unlike Mr. Edzio, who is depicted as if he does not possess any consciousness, class or otherwise, Isabelle, despite a stutter (which might signify the difficulty of the working class people to express themselves), is able to talk about her condition and fight for her rights. For the western viewer Rodak's and, by extension, Skolimowski's disinterest in, even contempt for the working class, as conveyed in Success (in the film reciprocated by the workers) might be difficult to reconcile with his unequivocal support of Solidarity, which was, predominantly, a workers' movement. This paradox can be explained by the anti-communist character of Solidarity opposition, which made it possible for a large section of the Polish intelligentsia to support it, without subscribing to its pro-workers character. Skolimowski's negative view of the working people, as devoid of dignity and agency, can be seen as a consequence of living under communism, where in official discourses the working class was regarded as a leading force of society, the nation's elite, at the expense of the intelligentsia. The director's mother was a victim of this approach, as her career in diplomacy was cut short due to her not belonging to the Party. It can also be linked to the legacy of his father who, as the director admitted, was very right wing (see Uszyski 1989: 5).

The staging of Alex's play, which has the same title as Skolimowski's film, Success Is the Best Revenge, excellently reveals the tension between patriotism and cosmopolitism in the life and work of Rodak (and Skolimowski). The form of this play is distinctively cosmopolitan. A "play" is not even the right word to describe Rodak's work, as in it he synthesises elements of different media, periods, and different discursive 
regimes, as well as multiplying the locations and breaking the divisions between stage and audience, performers and spectators, art and life. The scenes from Polish streets during martial law are reenacted by Polish non-actors, mostly emigrants working illegally in London. The scenes show encounters between police and workers, but it is also possible that, rather than acting, the emigrants, enraged by not being paid for their "spontaneous" performance, really do fight with each other. Their performance is accompanied by showing a football match between Poland and England on stage and on multiple screens, followed by the voice of the speaker (possibly Rodak) commenting on Polish history, while presenting pictures of events from the Yalta conference by Feliks Topolski, part of Topolski's Chronicle.

The commentary to these shows suggests that Rodak's project is not so much about martial law as about British and Western indifference to the Polish plight. This multimedia and multi-layered performance is viewed by spectators driven in buses, adding to the open character of the spectacle. In addition, Rodak's performance is open in the sense of crossing the boundaries between theatre and non-theatre. It is impossible to detect whether some scenes, such as the discussions between Montecurva and Polish performers, belong to the performance or are extraneous, as Skolimowski shoots them in such a way that they appear as an integral part of the play. The use of the same title for Rodak's and Skolimowski's project not only strengthens the autobiographical effect of the film, but adds to the openness of the film and the play. We do not learn what happens to Alex after the premiere of his work. Neither do we learn whether in Poland Adam found the genuine culture which he lacked in England or, indeed, whether he survived there. The lives of the Rodaks might go either way.

There is a similarity between Rodak's Success Is the Best Revenge and the theatrical experiments of Allan Kaprow, the pioneer of performance art and one of the most cosmopolitan artists of the twentieth century. However, while Kaprow's performances were a success, Rodak's show is a failure. The main reason seems to be the obsolescence of Rodak's project. While Kaprow's performances felt fresh and genuine in the 1950s, by the mid-1980s Success Is the Best Revenge comes across as outdated. Moreover, as Konrad Klejsa observes, the elements Rodak uses in his spectacle (a coffin, covered with black and red flowers, candles, a figure of the Holy Mary) after martial law became clichéd and treated with mistrust by the public (see Klejsa 2006: 155). Rodak's failure thus suggests that being successfully cosmopolitan means being ahead of one's times, embracing what is new in different cultures. However, his failure should not be equated with Skolimowski's failure because it could be argued that the director aimed at ridiculing patriotic art a la polacca and he succeeded.

On the whole, Success Is the Best Revenge (the film) comes across not only as the most autobiographical endeavour in Skolimowski's career, but also as one that is most difficult to comprehend. Even a viewer who knows the national and personal background to this film, is used to Skolimowski's trademark thematic shiftiness, gaps in the narrative, disrespect for psychological explanations and internal contradictions in the protagonists finds it difficult to make sense of this film. The idiosyncratic character of the film is a consequence of its autobiographical character: building it from what the director regarded as important for him personally (such as his son's thoughts), without attempting to censor its content or harness it by any form. In a sense, the film is like life itself: contradictory, open, painful to make and painful to watch. In Success Is the Best Revenge Skolimowski reached and, for the bulk of viewers, even crossed the border, when cinematic autobiography ceases being intersubjective and becomes not even a diary, but a kind of stream of consciousness or a polyphonic inner monologue, accessible only to the monologist himself. As Richard Combs aptly puts it, "This incorporation of the 'real' is more than realism would stand... And it is with such intense concentration on the real that surrealism begins" (Combs 1984: 390). Similarly, the director crossed the border where cinematic autobiography is viable as a commercial project. Not surprisingly, after this film Skolimowski resisted the temptation to place himself in the centre of the film and instead opted for a more subdued presence as an observer. Yet, despite being both a failure as an act of communication between the film author and the viewers and a commercial flop, Success Is the Best Revenge is a remarkable film precisely because it is so courageous in venturing into territory where few filmmakers dare to go. For any researcher interested in cinematic autobiography it is a must.

\section{Conclusion}

In conclusion I want to reiterate that autobiographism of Skolimowski's films is both complex and varied, as the director utilises many techniques to convey the impression that his films pertain to his life and persona, 
such as furnishing the narratives with personal data, casting members of his family and shaping his films as a kind of diary, with off-screen narration. It is a way to talk about himself, as well as his invented selves, but also to engage in wider discourses, such as provincialism/patriotism versus cosmopolitanism and young versus older generation. Autobiographism is an important reason why Skolimowski's cinema enjoys a cult following, especially in his native Poland, as it facilitates an intimate relationship between the author and the viewer. At the same time, it is a significant factor in why his films failed to attract larger audiences, especially in the West.

The presence of autobiographical discourse both links and distinguishes Skolimowski from Roman Polański. The films of both directors lend themselves to autobiographical reading, as both engage with such issues as the condition of an emigrant. Both directors also tended to cast their wives in their films. However, prior to making The Pianist (2002) Polański never revealed any desire to make films about his life and vigorously distanced himself from any attempt by the critics to see in his characters his hidden persona. By contrast, Skolimowski consciously and openly created his characters in his own image. It could be suggested that Polański is a filmmaker who draws on his life to furnish his characters and stories with authenticity. Skolimowski is a compulsive autobiographer who uses film as a medium to tell different versions of his own story.

\section{Notes}

1. The director himself, in an interview given many years later, compared making films to writing a diary (see Strick 1978: 147).

2. There are anecdotes about Skolimowski's resourcefulness. For example, Leon Niemczyk says "Skolimowski was a smart guy. He cast his Wartburg in the etude so that everyday an extra washed it for him at the expense of the taxpayer" (Niemczyk, quoted in Krubski et al 1998: 164). This anecdote puts in a particular light the on-screen renovating of the director's house in Moonlighting; one wonders whether the director made this film to have his house made over for him for free.

3. Nanni Moretti also chose this place to talk about Italy in his Aprile (1998).

4. A possible reason why this dichotomy gained such prominence in Success Is the Best Revenge, as well as in Skolimowski's previous film, concerning martial law, Moonlighting, was the fact that around this time hundreds of thousands of Poles faced a dilemma: emigrate or stay in Poland. Martial law thus added poignancy and currency to the discussion (always existent in Poland) about how best to serve one's country, who is the true patriot. In addition, the mass emigration drew attention to the question of options open to Polish emigrants; their chances to contribute to the material, social and cultural lives of their host countries and to preserve their Polish identity.

5. The idea that the artist must prostitute himself in order to find funds for his idealistic projects likens Success Is the Best Revenge with some films of Godard, especially Tout va bien (1972).

\section{References}

Boniecka, Ewa (1983). "Skolimowski na filmowym ringu," Życie Warszawy, 27/07, p. 8.

Buckley, Jerome Hamilton (1984). The Turning Key: Autobiography and the Subjective Impulse since 1800 (Cambridge, Massachusetts: Harvard University Press).

Chyła, Wojciech (1992). "Jerzy Skolimowski: Europeizacja polskości," Literatura, 6, pp. 13-7.

Combs, Richard (1984). "Success is the Best Revenge," Monthly Film Bulletin, 12, pp. 389-90.

Combs, Richard (1986). "Under Western Eyes: Skolimowski's Conradian Progress," Monthly Film Bulletin, 5, pp. 133-4. 
Eberhardt, Konrad (1982). Konrad Eberhardt o polskich filmach (Warszawa: Wydawnictwa Artystyczne i Filmowe).

Gazda, Janusz (1967). "Trzecie kino polskie - kino ironiczne," Ekran, 17, s. 3.

Helman, Alicja ed. (2002). Bolesław Michatek: Ambasador polskiego kina (Kraków: Rabid).

Jackiewicz, Aleksander (1983). Moja filmoteka: Kino polskie (Warszawa: Wydawnictwa Artystyczne i Filmowe).

Jankun-Dopartowa, Mariola (1997). "Rysopis jako duchowa biografia pokolenia," Kwartalnik Filmowy, 17, pp. 98-104.

Klejsa, Konrad (2004). "Jerzy Skolimowski - gry, maski, tsknoty, ucieczki... (cztery spojrzenia na wczesn twórczo)" in Grayna Stachówna and Joanna Wojnicka (eds) Mistrzowie kina polskiego (Kraków: Rabid), pp. 91-107.

Klejsa, Konrad (2006). "Obcy we mnie, obcy wród nas: Dowiadczenie emigracyjne w brytyjskich filmach Jerzego Skolimowskiego (Fucha i Najlepszą zemstą jest sukces)," Kwartalnik Filmowy, 53, pp. 142-57.

Kornacki, Krzysztof (2004). "Baśń Wielkanocna, czyli Bariera Jerzego Skolimowskiego obejrzana na nowo," Kino, 4, pp. 59-61.

Krubski, Krzysztof et al (1998). Filmówka: Powieść o Lódzkiej Szkole Filmowej (Warszawa: Tenten).

Lejeune, Philippe (1989). On Autobiography, trans. from French by Katherine Leary (Minneapolis: University of Minnesota Press).

Lichocka, Joanna (1994). "Z dou do góry, z góry na dó...," Uroda, 2, pp. 6-9.

Naficy, Hamid (2001). An Accented Cinema: Exilic and Diasporic Filmmaking (Princeton: Princeton University Press).

Pascal, Roy (1960). Design and Truth in Autobiography (London: Routledge \& Kegan Paul).

Pogorzelska, Joanna (2001). "Sukces jest najlepszą zemstą," Magazyn Gazety (the supplement to Gazeta Wyborcza), 8/02, pp. 20-4.

Polanski, Roman (1984). Roman by Polanski (London: Heinemann).

Ronduda, Łukasz (2007). "Skolimowski, Królikiewicz, Żuławski, Uklański, czyli wypisy z historii polskiej nowej fali," Obieg, 1/11, http://www.obieg.pl/text/07110101.php.

Sontag, Susan (1983). "Under the Sign of Saturn" in her Under the Sign of Saturn (London: Writers and Readers), pp. 109-134.

Sontag, Susan (1994). "A note on novels and films" in her Against Interpretation (London: Vintage), pp. $242-5$.

Strick, Philip (1978). "Skolimowski's Cricket Match," Sight and Sound, Summer, pp. 146-7.

Uszyński, Jerzy (1989). "Ousiderzy są zmęczeni?," Kino, 11, pp. 4-7.

Uszyński, Jerzy (1990). "Jerzy Skolimowski o sobie: Całe życie jak na dłoni," Film na wiecie, 379, pp. 3-47.

Walker, Michael (1970). "Jerzy Skolimowski" in Ian Cameron (ed.) Second Wave: Newer than New Waves Names in World Cinema (London: Studio Vista), pp. 34-62.

Wertenstein Wajda ed. (1991). Wajda mówi o sobie: Wywiady i teksty (Kraków: Wydawnictwo Literackie). Ziółkowski, Bohdan (1967). "Rozmowa z Jerzym Skolimowskim," Odgłosy, 42, p. 8-9. 


\section{Author Information}

Ewa MAZIERSKA is Professor of Contemporary Cinema at the Department of Humanities, University of Central Lancashire. Her publications include Masculinity in Polish, Czech and Slovak Cinema, Roman Polanski: The Cinema of a Cultural Traveller, Women in Polish Books (with Elżbieta Ostrowska), Crossing New Europe: The European Road Movie (with Laura Rascaroli), Dreams and Diaries: The Cinema of Nanni Moretti, and From Moscow to Madrid: Postmodern Cities, European Cinema. She also co-edited Relocating Britishness. 